\title{
Pengaruh Penambahan Aspergilllus niger terhadap Kandungan Nutrien pada Proses Fermentasi Kulit Buah Kakao (Theobroma cacao)
}

\section{Effect of Adding Aspergillus niger on the Nutrient Content in the Fermentation Process of Cocoa Pods}

\section{Engkus Ainul Yakin*, Ahimsa Kandi Sariri, Sri Sukaryani}

Program Studi Peternakan Fakultas Pertanian, Universitas Veteran Bangun Nusantara Sukoharjo. Jl. Letjen Sujono Humardani No. 1, Sukoharjo 57521. Jawa Tengah. Indonesia

Article history

Received: May 14, 2020;

Accepted: Aug 27, 2020

* Corresponding author:

E-mail:

engkus_ainul@yahoo.com

DOI:

10.46549/jipvet.v10i2.109

\section{Abstract}

This research goal is to determine the nutrient content increased and decreased lignin content of cocoa pod fermented by Aspergillus niger. The assessment method was performed using the three treatments and four replications. $\mathrm{T} 0=$ cocoa pod fermentation without the addition of Aspergillus niger, $\mathrm{T} 1=$ cocoa pod fermentation by the addition of $5 \%$ Aspergillus niger, and $\mathrm{T} 2$ = cocoa pod fermentation by the addition of $10 \%$ of Aspergillus niger. Fresh cocoa pods were chopped to a size of $1-2 \mathrm{~cm}$. Some of the cocoa pods are directly chopped, rolled, and dried while the rest are supplemented with Aspergillus niger. The mixture is stored within an aerobic medium for seven days. Observed variables include dry matter (DM), crude protein $(\mathrm{CP})$, crude fiber $(\mathrm{CFt})$, crude fat $(\mathrm{CF})$, and lignin. Data were analyzed with analysis of variance unidirectional pattern (Oneway ANOVA) of the completely randomized design (completely randomized design), then if there are significant differences will be further tested by Duncan multiple range test. The results showed that cocoa pod fermented with A. niger decrease of dry matter, crude fat, crude fiber, and lignin. The conclusion is the addition of Aspergillus niger 5\% will lower the lignin content (5.38\%) compared to without the addition of Aspergillus niger (7.84\%).

Keywords: Aspergillus niger; Cocoa pod; Fermentation; Lignin

\section{Abstrak}

Penelitian dilakukan untuk mengetahui peningkatan kandungan nutrien dan penurunan kandungan lignin dari kulit buah kakao (KBK) yang difermentasi dengan $A$. niger. Metode penelitian yang dilakukan yaitu menggunakan tiga perlakuan dan empat ulangan. $\mathrm{P} 0=\mathrm{KBK}$ fermentasi tanpa penambahan A. niger, $\mathrm{P} 1=\mathrm{KBK}$ fermentasi dengan penambahan $5 \%$ A. niger, dan $\mathrm{P} 2=\mathrm{KBK}$ fermentasi dengan penambahan $10 \%$ A. niger. KBK segar dicacah dengan ukuran 1-2 cm. Sebagian KBK yang dicacah langsung dikeringkan kemudian digiling dan sebagian lainnya diberi penambahan A. niger. Campuran dimasukkan ke dalam wadah aerob selama 7 hari. Penelitian ini dirancang menggunakan desain penelitian rancangan acak lengkap. Variabel yang diamati meliputi kandungan bahan kering (BK), protein kasar (PK), serat kasar (SK), lemak kasar (LK) dan lignin. Data dianalisis menggunakan sidik ragam pola searah (oneway ANOVA) dan dilanjutkan uji jarak berganda Duncan (Duncan multiple range test/DMRT), apabila nilai $\mathrm{P}<0,05$. Hasil penelitian menunjukkan bahwa fermentasi kulit buah kakao dengan $A$. niger menurunkan kandungan air, lemak kasar, serat kasar dan lignin. Disimpulkan bahwa penambahan A. niger 5\% dapat menurunkan kandungan lignin $(5,38 \%)$ dibandingkan dengan tanpa penambahan A. niger $10 \%$ $(7,84 \%)$.

Kata kunci : Aspergillus niger; Fermentasi; Kulit buah kakao; Lignin 


\section{PENDAHULUAN}

Permasalahan utama dalam pengembangan produksi ternak ruminansia di Indonesia yaitu memenuhi ketersediaan pKn secara berkesinambungan baik mutu maupun jumlahnya. Usaha pemanfaatan sisa hasil (limbah) pertanian untuk pakan ternak perlu dipadukan dengan bahan lain yang sampai saat ini belum biasa digunakan sebagai pakan.

Limbah tanaman pertanian dan perkebunan memiliki peran yang cukup penting dalam penyediaan pakan hijauan bagi ternak ruminansia seperti sapi, kambing, domba dan kerbau terutama pada musim kemarau. Pada musim kemarau hijauan rumput terganggu pertumbuhannya, sehingga pakan hijauan yang tersedia kurang baik dari segi kuantitas maupun kualitas. Bahkan di daerah-daerah tertentu rumput akan kering dan mati sehingga menimbulkan krisis pakan hijauan. Faktor pembatas dari pemanfaatan hasil sisa tanaman sebagai pakan yaitu kadar protein yang rendah dan terjadi proses lignifikasi lanjut sehingga selulosa terikat oleh lignin.

Permasalahan kekurangan pakan hijauan tersebut, diharapkan peternak bisa memanfaatkan limbah pertanian yang cukup banyak tersedia disekitarnya antara lain kulit buah kakao, pucuk tebu, jerami padi, jerami jagung, jerami kedelai dan jerami kacang tanah melalui perlakuan tertentu.

Kulit buah kakao dapat dijadikan sebagai bahan pakan alternative untuk ternak ruminansia. Pemanfaatan KBK sebagai pakan ternak ruminansia di lapangan masih belum optimal, sebagian dibuang atau disebar dibawah pohon kakao. Kulit buah kakao layak dikonsumsi ternak ruminansia hanya tiga hari setelah panen. Munier et al. (2005) melaporkan bahwa KBK layak dikonsumsi ternak ruminansia hingga hari ketiga setelah panen, setelah hari keempat KBK sudah mulai ditumbuhi jamur dan berbau asam.

Kulit buah kakao sebagai pakan ternak dapat diberikan dalam bentuk segar maupun dalam bentuk tepung setelah diolah. Hasil penelitian menunjukkan bahwa kulit buah kakao segar yang dikeringkan dengan sinar matahari kemudian digiling selanjutnya dapat digunakan sebagai bahan pakan ternak.
Kulit buah kakao adalah merupakan limbah sisa hasil pertanian yang dihasilkan tanaman kakao (Theobroma cacao L.) Buah kakao terdiri atas $74 \%$ kulit buah, $2 \%$ plasenta dan $24 \%$ biji. Hasil analisis proksimat KBK mengandung $22 \%$ protein dan 3-9 \% lemak (Nasrullah dan Ella, 1993). Munier (2007) melaporkan KBK kandungan nutrien BK $18,7 \%$, PK 9,9 \%, SK 32,9 \% dan LK 9,2\%, sedangkan Alemawor et al. (2009) melaporkan bahwa KBK yang tidak terfermentasi memiliki komponen dinding sel KBK yakni hemiselulosa $11 \%$, selulosa $35 \%$, lignin $14 \%$, dan pektin $6 \%$.

Kendala utama pemanfaatan KBK sebagai pakan ternak yaitu kandungan serat kasar tinggi dan protein rendah. Pengolahan kulit buah kakao menjadi tepung kemudian difermentasi dengan jasa kapang merupakan salah satu cara untuk meningkatkan kualitas nutrien KBK. Hasil penelitian pada ternak domba menunjukkan bahwa penggunaan KBK dapat digunakan sebagai substitusi suplemen sebanyak $15 \%$ atau $5 \%$ dari ransum. Sebelum digunakan sebagai pakan ternak, limbah kulit buah kakao sebaiknya perlu difermentasikan terlebih dahulu untuk menurunkan kadar lignin yang sulit dicerna oleh hewan dan untuk meningkatkan kadar protein dari 6-8 \% menjadi $12-15 \%$.

Tujuan penelitian ini yaitu mengkaji kandungan nutrien dan penurunan kandungan lignin dalam KBK yang difermentasi dengan $A$. niger.

\section{MATERI DAN METODE}

Kulit buah kakao segar dikumpulkan dari Kecamatan Girimarto Kabupaten Wonogiri dibawa ke laboratorium untuk difermentasi. Kulit buah kakao difermentasi dalam kotak plastik dan aerasi dijaga dengan melubangi bagian bawah dan samping kotak. Seratus gram KBK digunakan untuk setiap kotak plastik dan ditaburi dengan A. niger. Suhu ruang fermentasi dipertahankan pada kisaran $28-30^{\circ}$ C dengan kelembapan $75-85 \%$ agar pertumbuhan Apergillus niger optimal. Fermentasi dilakukan selama 7 hari.

Penelitian ini menggunakan rancangan acak lengkap pola searah. Tiga perlakuan dengan empat ulangan yang digunakan yaitu : $\mathrm{P} 0=\mathrm{KBK}$ fermentasi tanpa penambahan $A$. 
niger, $\mathrm{P} 1=\mathrm{KBK}$ fermentasi dengan penambahan $5 \%$ A. niger dan $\mathrm{P} 2=\mathrm{KBK}$ fermentasi dengan penambahan $10 \%$ A. niger. Penambahan $A$. niger berdasarkan berat bahan kering.

Variabel yang diamati yaitu BK, PK, LK, $\mathrm{SK}$, dan lignin. Data yang diperoleh dianalisis dengan menggunakan analisis sidik ragam pola searah dan dilanjutkan dengan uji Duncan's
Multiple Range Test (DMRT) (Christensen, 1996) apabila terdapat perbedaan.

\section{HASIL DAN PEMBAHASAN}

Data rata-rata komposisi kimia yang meliputi BK, PK, LK, SK, dan lignin dari ketiga perlakuan selama penelitian tertera pada Tabel.

Tabel. Rerata komposisi nutrien fermentasi kulit buah kakao dengan pemberian 0, 5 dan $10 \%$ A. niger (\%)

\begin{tabular}{|c|c|c|c|}
\hline \multirow{2}{*}{$\begin{array}{l}\text { Komposisi } \\
\operatorname{Kimia}(\%)\end{array}$} & \multicolumn{3}{|c|}{ Perlakuan } \\
\hline & P0 & P1 & $\mathbf{P 2}$ \\
\hline Bahan kering & $27,31^{b} \pm 0,12$ & $22,46^{\mathrm{a}} \pm 0,92$ & $22,26^{\mathrm{a}} \pm 0,51$ \\
\hline Protein kasar & $2,45^{\mathrm{b}} \pm 0,29$ & $1,67^{\mathrm{a}} \pm 0,24$ & $2,05^{\mathrm{ab}} \pm 0,26$ \\
\hline Lemak kasar & $1,02^{b} \pm 0,12$ & $0,68^{a} \pm 0,69$ & $0,65^{\mathrm{a}} \pm 0,03$ \\
\hline Serat kasar & $8,37^{c} \pm 0,52$ & $5,41^{\mathrm{a}} \pm 0,13$ & $7,01^{\mathrm{b}} \pm 0,33$ \\
\hline Lignin & $7,84^{b} \pm 0,61$ & $5,38^{a} \pm 0,25$ & $5,74^{\mathrm{a}} \pm 0,29$ \\
\hline
\end{tabular}

\section{BAHAN KERING}

Rata-rata kandungan BK tertera dalam pada Tabel. Perlakuan P0 menunjukkan hasil yang berbeda nyata $(\mathrm{P}<0,05)$ bila dibandingkan $\mathrm{P} 1$ dan $\mathrm{P} 2$, sedangkan $\mathrm{P} 1$ dan $\mathrm{P} 2$ menunjukkan hasil yang berbeda tidak nyata.

Bila dilihat dari rata-rata BK ketiga perlakuan berturut-turut yaitu $\mathrm{P} 0=27,31 \pm$ $0,12, \mathrm{P} 1=22,46 \pm 0,92$, dan $\mathrm{P} 2=22,26 \pm 0,51$ $\%$. Angka tersebut menunjukkan bahwa kandungan BK pada perlakuan P1 dan P2 lebih rendah dibanding dengan P0. Kandungan BK KBK setelah mengalami proses fermentasi mengalami penurunan. Lignin sebagai komponen serat yang tidak dapat digunakan kapang sebagai sumbr energi utama. Oleh karena itu kapang memanfaatkan BO lainnya dari substrat dan mengakibatkan terjadinya perubahan BK dan BO (Suparjo et al., 2009). Lebih lanjut menurut Suparjo et al. (2009) menyatakan bahwa penurunan BK KBK yang difermentasi dengan menggunakan Phanerochaete chrysosporium selama 5 hari yaitu $5,52 \%$. Hal ini disebabkan karena pada substrat KBK ditambahkan mineral Mangan $(\mathrm{Mg})$. Fungsi mineral ini dapat meningkatkan laju pertumbuhan dan memperpanjang miselium kapang, dengan penambahan mineral ini maka penggunaan BK lebih efisien.

\section{PROTEIN KASAR}

Rata-rata kandungan PK tertera dalam Tabel. Perlakuan P0 menunjukkan hasil yang berbeda nyata bila dibandingkan P1, sedangkan P2 menunjukkan hasil yang berbeda tidak nyata $(\mathrm{P}<0,05)$ bila dibandingkan dengan $\mathrm{P} 0$ maupun P1.

Bila dilihat dari rata-rata $\mathrm{BK}$ ketiga analisis proksimat perlakuan berturut-turut yaitu $\mathrm{P} 0=$ $2,45 \pm 0,29, \mathrm{P} 1=1,67 \pm 0,24$, dan $\mathrm{P} 2=2,05 \pm$ $0,26 \%$. Angka tersebut menunjukkan bahwa PK pada perlakuan P1 dan P2 lebih rendah dibanding dengan P0. Hal ini menunjukkan bahwa pada perlakuan P1 dan P2 yang diberi penambahan $A$. niger tidak memberikan kenaikan terhadap PK, justru P0 yang tidak diberikan penambahan $A$. niger memberikan hasil kandungan PK yang lebih tinggi dibanding pada P1 dan P2.

Hasil penelitian ini lebih rendah dibandingkan hasil penelitian sebelumnya yang dilaporkan oleh Laconi (1998) bahwa KBK yang difermentasi menggunakan kapang Phanerochaete chrysosporium yang ditambahkan mollases 3\% dari berat media yaitu dengan perubahan kearah kenaikan kandungan PK 20,72\%. Sementara Sutikno et al. (1994) melaporkan bahwa KBK yang difermentasi menggunakan $A$. niger dengan penambahan unsur urea dan mineral 
berpengaruh nyata terhadap peningkatan kandungan PK dari 5,88\% naik menjadi $10,73 \%$ pada fermentasi 4 hari atau terjadi kenaikan 47,91\%. Lateef et al. (2008) menyebutkan bahwa pada media yang sama menggunakan kapang Rhizopus stolonifer LAU 07 dan diberikan sukrosa 20\% dengan perubahan kenaikan PK mencapai 95\%. Hal tersebut menunjukkan bahwa penambahan urea, mineral dan karbohidrat tersedia dapat lebih meningkatkan kinerja kapang dalam proses enzimatik protease yang diikuti dengan kenaikan kandungan PK KBK yang optimal.

\section{LEMAK KASAR}

Rata-rata proksimat LK tertera dalam Tabel. Perlakuan P0 menunjukkan hasil yang berbeda nyata $(\mathrm{P}<0,05)$ bila dibandingkan $\mathrm{P} 1$ dan P2, sedangkan P1 dan P2 menunjukkan hasil yang berbeda tidak nyata.

Bila dilihat dari rata-rata LK ketiga perlakuan berturut-turut yaitu $\mathrm{P} 0=1,02 \pm 0,12$, $\mathrm{P} 1=0,68 \pm 0,69$, dan $\mathrm{P} 2=0,65 \pm 0,03 \%$. Angka tersebut menunjukkan bahwa LK pada perlakuan P1 dan P2 lebih rendah dibanding dengan P0. Hal ini menunjukkan bahwa pada perlakuan P1 dan P2 yang diberi penambahan A. niger tidak memberikan kenaikan terhadap LK, justru $\mathrm{P} 0$ yang tidak diberikan penambahan A. niger memberikan hasil kandungan LK yang lebih tinggi dibanding pada P1 dan P2. Hal ini karena kapang tersebut menggunakan LK sebagai sumber energi. Lemak memiliki fungsi utama sebagai energi cadangan dalam bentuk trigliserida (Toha, 2005). Menurut Hamid et al. (1999) bahwa enzim lipase pada A. niger memiliki peranan dalam menghidrolisis lemak menjadi gliserol dan asam lemak dengan adanya molekul air. Aktifitas kapang ini yang menyebabkan penurunan kandungan LK KBK pada fermentasi menggunakan A. niger.

Tingginya penurunan LK KBK pada penelitian ini disebabkan karena keterbatasan energi yang tersedia bagi kapang untuk menguraikan fraksi serat dan alkaloid KBK sehingga LK digunakan sebagai sumber energi.

\section{SERAT KASAR}

Rata-rata proksimat SK tertera dalam Tabel. Pada semua perlakuan menunjukkan hasil yang berbeda nyata. Bila dilihat dari ratarata SK ketiga perlakuan berturut-turut yaitu $\mathrm{P} 0$ $=8,37 \pm 0,52, \mathrm{P} 1=5,41 \pm 0,13$, dan $\mathrm{P} 2=7,01$ $\pm 0,33 \%$. Angka tersebut menunjukkan bahwa proksimat SK pada perlakuan P0, P1 dan P2 menunjukkan beda nyata antar semua perlakuan. SK perlakuan P1 lebih rendah dibanding dengan P0 dan P2. Penambahan $A$. niger $5 \%$ pada fermentasi kulit buah kakao memberikan hasil yang lebih baik dibandingkan dengan pemberian $10 \%$ maupun tanpa penambahan Aspergillus niger terhadap serat kasar.

Fermentasi pada penelitian ini hanya menggunakan $A$. niger tanpa penambahan bahan aditif lainnya, sehingga apabila dibandingkan dengan penelitian sejenis yang menggunakan bahan aditif menunjukkan hasil SK KBK yang berbeda. Alemawor et al. (2009) melaporkan bahwa terjadi penurunan kandungan SK KBK sebesar 7,64\% dengan menggunakan Aspergillus spp dan ditambahkan enzim glukanase dan xylanase. Menurut Smith (2002) dan Andayani (2008) bahwa larutan urea berfungsi untuk merenggangkan atau menguraikan ikatan lignohemiselulosa dan lignoselulosa pada limbah pertanian. Hasil penelitian Laconi (1998) menyebutkan bahwa terjadi penurunan kandungan SK KBK sebesar 18,16\% dengan menggunakan kapang Phanerochaete chrysosporium, partikel cacahan KBK 5-7 mm dan ditambahkan molases 3\% dari total media.

Penurunan kandungan SK KBK ini lebih banyak dipengaruhi oleh aktifitas enzim yang dihasilkan oleh Aspergillus niger. Aspergillus niger menghasilkan bermacam-macam enzim seperti enzim mannase, selulase dan enzimenzim pemecah karbohidrat lainnya sehingga dalam prose fermentasi kapang ini mampu menguraikan serat lebih optimal (Wina, 2005).

\section{LIGNIN}

Rata-rata kandungan lignin tercantum pada Tabel. Perlakuan P0 menunjukkan hasil yang berbeda nyata bila dibandingkan P1 dan P2, sedangkan P1 dan P2 menunjukkan hasil yang berbeda tidak nyata.

Bila dilihat dari rata-rata lignin ketiga perlakuan berturut-turut yaitu $\mathrm{P} 0=7,84 \pm 0,61$, $\mathrm{P} 1=5,38 \pm 0,25$, dan $\mathrm{P} 2=5,74 \pm 0,29 \%$. Angka tersebut menunjukkan bahwa lignin pada perlakuan P0 menunjukkan beda nyata $(\mathrm{P}<0,05)$ bila dibandingkan dengan $\mathrm{P} 1$ dan $\mathrm{P} 2$. Kandungan lignin $\mathrm{P} 1$ dan $\mathrm{P} 2$ yang diberi 
penambahan $A$. niger memiliki kandungan lignin yang lebih rendah bila dibandingkan dengan P0. Penambahan A. niger 5\% dengan penambahan $A$. niger $10 \%$ pada fermentasi kulit buah kakao memberikan hasil yang berbeda tapi tidak nyata terhadap kandungan lignin.

Pada KBK dilaporkan memiliki kadar lignin dan tanin masing-masing sebesar $23,65 \%$ dan $0,84 \%$ sehingga memiliki kecernaan bahan kering rendah yaitu 29,27\% (Rinduwati dan Ismartoyo, 2002).

Lignin merupakan salah satu polimer fenilpropanoid yang sulit dirombak karena strukturnya heterogen dan sangat kompleks. Lebih dari $30 \%$ material tumbuhan tersusun oleh lignin, sehingga dapat memberikan kekuatan pada kayu terhadap serangan mikroorganisme (Orth et al., 1993).

Kelompok kapang white-rot umumnya mensintesis 3 macam enzim, yaitu Ligninperoksidase (LiP), Manganese-peroksidase (MnP) dan Laccase. Ketiga enzim sangat berperan dalam proses degradasi lignin (Srinivasan et al., 1995). Enzim-enzim tersebut mampu mengoksidasi senyawa-senyawa fenol. Reaksi degradasi lignin oleh basidiomisetes dikatalisis oleh enzim lignin peroksidase, $\mathrm{Mn}$ peroksidase (Addleman et al., 1993; Dozoretz et al., 1993). Kapang pendegradasi kayu mampu mensintesis satu atau dua jenis enzim tersebut di atas, misalnya Phanerochaete chrysosporium, Trametes versicolor mampu mengekskresikan lignin-peroksidase dan manganese-peroksidase ke dalam medium, sedangkan kelompok brown- rot fungi hanya mampu mensintesis lignin-peroksidase saja.

\section{KESIMPULAN}

Fermentasi kulit buah kakao menggunakan A. niger dapat menurunkan kandungan lignin dari $7,84 \%$ menjadi $5,38 \%$.

\section{DAFTAR PUSTAKA}

Addleman K. and Archibald F. 1993. Kraft Pulp Bleaching and Delignification by Dikaryons and Monokaryon of Trametes versicolor. Applied and Environmental Microbiology, 59(1): 266-273

Alemawor F., Dzogbefia V. P., Oddoye E. O. K. and Oldham J. J. H.. 2009. Enzyme cocktail for enhancing poultry utilization of cocoa pod husk composition. Scientific Research and Essay. 4(6): 555-559.

Christensen R. 1996. Analysis of variance, Design and Regession: Applied Statistical Methods. Chapman and Hall. London

Dozoretz C.G., Rothschild N. and Hadar Y. 1993. Over production of lignin Peroxidase by Phanerochaete chrysosporium BKMF1767. Applied and Environmetal Microbiology, 59(6): 1919-1926

Hamid H., Purwadaria, T. Haryati T. dan Sinurat P. 1999. Perubahan nilai bilangan peroksida bungkil kelapa dalam proses penyimpanan dan fermentasi dengan Aspergillus niger. Jurnal Ilmu Ternak dan Veteriner. 4: 101-106.

Hardianto R. dan Sunandar N. 2009. Petunjuk Teknis Pembuatan Pakan Lengkap untuk Ternak Ruminansia. Balai Pengkajian Teknologi Pertanian (BPTP) Jawa Barat Balai Besar Pengkajian Dan Pengembangan Teknologi Pertanian Badan Penelitian dan Pengembangan Pertanian Departemen Pertanian

Laconi E. B. 1998. Peningkatan Mutu Pod Cacao Melalui Amoniasi dengan Urea dan Biofermentasi dengan Phanerochaete chrysosporium serta Penjabarannya ke dalam Formulasi Ransum Ruminansia. Disertasi. Program Pascasarjana Institut Pertanian Bogor, Bogor.

Lateef A., Oloke E. B. G. Kana S. O., Oyeniyi O. R., Onifade A. O., Oyeleye O. C., Olasadu A. O. and Oyelami. 2008. Improving the quality of agro-wastes by solid-state fermentatiton ; Enhanced antioxidant activities and nutritional qualities. Journal of Microbiology and Biotechnology. 24: 2369-2374. DOI : 10.1007/s11274-008-9749-8.

Munier F. F. 2009. Potensi ketersediaan kulit buah kakao (Theobroma cacao L.) sebagai sumber pakan alternatif untuk ternak ruminansia di Darah Istimewa Yogyakarta. Pros. Sem. Nas. Teknologi Peterrnakan dan Veteriner, Bogor 13-14 Agustus 2009. 752-759.

Munier F.F., Ardjanhar A., Fadjar U., Priyanto D., Syafruddin, Femmi N.F., Langsa Y. dan Wiryadiputra S. 2005. Laporan hasil pengkajian pengembangan sistem usaha 
tani integrasi kambing dan kakao di Sulawesi Tengah TA. 2005. Kerjasama BPTP Sulteng dengan LRPI Bogor dan Puslitbangnak Bogor.

Nasrullah dan Ella A. 1993. Limbah Pertanian dan Prospeknya Sebagai Sumber Pakan Ternak di Sulawesi Selatan. Makalah. Ujung Pandang.

Orth A. B., Royse D.J. and Tien M. 1993. Ubiquity of Lignin Peroxidase among Various Wood-Degrading Fungi. Applied Environmental Microbiology. 59(12): 4017-4023

Rinduwati dan Ismartoyo. 2002. Karakteristik degradasi beberapa jenis pakan (in sacco) dalam rumen ternak kambing. Bulletin Nutrisi dan Makanan Ternak 31: 1 - 14.

Smith T. 2002. On-farm treatment of straw and stover with urea. Proc. Of The Final Review Meeting of an IAEA Technical CoOperation Regional AFRA Project. Cairo Egypt. 25-29 Nov 2000. Oraganized by FAO/IAEA Division of Nuclear Tecniques in Food and Agriculture. pp 15-22.
Srinivasan C., Souza T. M. D., Boominathan K. and Reddy C. A. 1995. Demonstration of Laccase in the White Rot Basidiomycete Phanerochaete chrysosporium. Applied Environmental Microbiology. 61(2): 42744277.

Suparjo K.G., Wiryawan E. B. Laconi dan Mangunwidjaja D. 2009. Perubahan komposisi kimia kulit buah kakao akibat penambahan mangan dan kalsium dalam biokonversi dengan kapang Phanerocahete chrysosporium. Media Peteternakan 32. (3) : 203-210.

Sutikno A. I., Haryati T. dan Darma J. 1994. Perbaikan kualitas gizi pod coklat melalui proses fermantasi. Buku 2. Pros. Sem. Sains dan Teknologi Peternakan. Pengolahan dan dan Komunikasi HasilHasil Penelitian, Ciawi-Bogor 25-26 Januari 1994. Balitnak, Puslitbangnak., Badan Litbangtan., Bogor. 753-76.

Toha A. H. A. 2005. Biokimia : Metabolisme Biomolekul. Cetakan Kedua. Alfabeta, Bandung. pp 99-121. 